\title{
LEARNING FROM BEAR-WALKER: INDIGENOUS LEGAL ORDERS INTERCULTURAL LEGAL EDUCATION IN CANADIAN LAW SCHOOLS
}

\author{
Hannah Askew*
}

This article investigates educational strategies that law schools could implement to honour Recommendation \#28 of the Truth and Reconciliation Commission and foster strong intercultural interpretation and communication skills amongst new generations of legal professionals in relation to Indigenous legal viewpoints. The paper is divided into four sections: the first draws on Indigenous legal scholarship to explore definitions of Indigenous law; the second provides a case study of one method of learning Indigenous law based on the author's personal experiences of being taught Annishinabe law at Neyaashiinigmiing (a reserve community on Georgian Bay); the third discusses some of the initiatives, opportunities and challenges involved in integrating Indigenous legal traditions into the curriculum of Canadian law schools; and the fourth and final section highlights some of the concerns being raised as these initiatives develop, and the related need for the legal profession to proceed with caution and humility.

Cet article porte sur les stratégies d'éducation que les écoles de droit pourraient mettre en ouvre pour donner suite à la recommandation $n^{\circ} 28$ de la Commission de vérité et de réconciliation et promouvoir de fortes aptitudes en interprétation et communications interculturelles chez les nouvelles générations de professionnels du droit en ce qui concerne les points de vue juridiques autochtones. Le texte compte quatre sections : la première présente diverses définitions juridiques fondées sur la théorie $d u$ droit autochtone; la deuxième traite d'une méthode d'apprentissage du droit autochtone fondée sur l'expérience que l'auteure a vécue lorsqu' elle a fait l'apprentissage de la loi anishinaabe à Neyaashiinigmiing (communauté vivant sur une réserve indienne située dans la baie Georgienne); la troisième porte sur les initiatives, possibilités et défis liés à l'intégration des traditions juridiques autochtones dans le programme des écoles de droit canadiennes; enfin, la quatrième et dernière section met en relief quelques-unes des préoccupations soulevées au fur et à mesure que ces initiatives prennent forme, et la nécessité pour la profession juridique de faire preuve de prudence et d'humilité.

Hannah Askew is staff counsel at West Coast Environmental Law in Vancouver, British Columbia, where she practices environmental and Aboriginal law. This article was generously funded by a fellowship grant from the Chief Justice of Ontario's Advisory Committee on Professionalism. The author wishes to express her gratitude to the following individuals for helpful conversations and for sharing insights that shaped the content of this article: Ben Berger, John Borrows, Lindsay Borrows, Jennifer Borrows, Jean Borrows, Joseph Borrows, Tony Cheghano, Mark Ebert, Hadley Friedland, Basil Johnston, Kent McNeil, Wendall Nadjiwon, Wilmer Nadjiwon, Val Napoleon, Neepitapinaysiqua, Rupert Ross, and two anonymous reviewers. 
How can we make space within the legal landscape for Indigenous legal orders? The answer depends, at least in part, on an inversion of the question: a crucial part of this process must be to find space for ourselves, as strangers and newcomers, within the Indigenous legal orders themselves.

- Honourable Justice Lance SG Finch “The Duty to Learn: Taking Account of Indigenous Legal Orders in Practice" (November 2012)

Interest in serious and sustained engagement with Indigenous legal traditions is building within Canada, across professional, academic, and Indigenous communities. If the momentum is going to be sustained and grow productively, then we need shared frameworks for engaging with Indigenous legal traditions within and across these same Indigenous, professional, and academic communities. ${ }^{1}$

- Val Napoleon and Hadley Friedland, “The Inside Job: Engaging with Indigenous Legal Traditions through Stories" (forthcoming)

\section{INTRODUCTION}

In Basil Johnston's story "The Bear-Walker" ("Mukwo-bimossae"), a young man travels from Toronto to Manitoulin Island to ask Bear-Walker to teach him how to find medicine. He is not sure exactly what he wants to learn, but he knows he wants to learn good medicine to be able to help others. Bear-Walker agrees to his request saying, "Very well, I'll teach you, but it will not be fast, rest assured."

Over the next several days, Bear-Walker takes the young man out on the land along a river and to a pond, asking him what he sees. "Nothing," the young man replies on each occasion. Quickly, the young man grows impatient, feeling he is learning nothing and that Bear-Walker is a slow teacher.

One day when they reach the pond, Bear-Walker points to a water lily growing near the centre and asks the young man to bring it to him. The young man wades into the dank water as far as his knees, and offers to pick a lily there. Bear-Walker waves him on towards the deeper water. The young man stops again when the water is at his waist, and offers to pick a lily there. Again Bear-Walker waves him on to go deeper. The young man continues until he reaches a lily in the middle of the pond and is up to his neck in dank, foul-smelling water. "Is this the one?" He calls to Bear-Walker.

Bear-Walker calls back "Yes, that's the one!" The young man is about to break off the stem when Bear-Walker calls out "No! Don't pick it! I want the whole plant, what's underwater also."

The young man put his hands underwater and pulls on the stem but the plant won't pull out. He shouts to Bear-Walker that it is stuck. The young man doesn't want to put his head beneath the dirty, rank-smelling water. He pulls and pulls but the lily is stuck. Finally, he holds his breath and dives into the murky water. He digs underneath the plant and pulls out the roots, bringing up the entire plant. He carries it back to the shore and gives it to Bear-Walker.

1 Val Napoleon \& Hadley Friedland, "The Inside Job: Engaging with Indigenous Legal Traditions through Stories" in Tony Lucero \& Dale Turner, eds, Oxford Handbook on Indigenous Peoples' Politics (Oxford: Oxford University Press, forthcoming) [Napoleon \& Friedland, "The Inside Job"]. 
Bear-Walker asks him what he has learned. "Nothing," replies the young man, "Except that you really wanted this plant." Bear-Walker encourages him to reflect more deeply but the young man is tired and frustrated. He feels that Bear-Walker is not teaching him, so rather than persevere, he quits. Years later, when the young man has grown older, and is sitting at home, he suddenly exclaims "That's it! That's what Bear-Walker was trying to teach me."

After seven years of collecting evidence, the Truth and Reconciliation Commission (TRC) has issued ninety-four recommendations and a Call to Action. Recommendation 28 addresses Canadian legal education:

We call upon law schools in Canada to require all law students to take a course in Aboriginal people and the law, which includes the history and legacy of residential schools, the United Nations Declaration on the Rights of Indigenous Peoples, Treaties and Aboriginal rights, Indigenous law, and Aboriginal-Crown relations. This will require skills-based training in intercultural competency, conflict resolution, human rights, and anti-racism. ${ }^{3}$

In the wake of this clear call to action, Canadian law schools find themselves, like the young man in the Bear-Walker story, in the position of seeking a teacher who can help them. Among other areas, Recommendation 28 highlights the need for emerging legal professionals to learn Indigenous law. This educational requirement is also consistent with directives contained in a number of Supreme Court of Canada decisions. ${ }^{4}$

While the recommendation itself is clear, the steps required to effectively implement it are much murkier and raise challenging questions: what is Indigenous law; how is Indigenous law taught; who can teach Indigenous law; and where can Indigenous law be learned? This article seeks to take up the TRC's call to action on legal education by exploring some of the practical questions involved in integrating the teaching of Indigenous law into Canadian law schools. It also suggests that exploring these questions may not lead to quick and obvious answers and may take many of us out of our comfort zones, much as the young man in the Bear-Walker story experiences.

This discussion is not only relevant to law professors and students. In a much-discussed paper presented in 2012, Chief Justice Lance Finch of the British Columbia Court of Appeal argued that the honour of the Crown demands of all legal professionals "a duty to learn" about Indigenous legal orders.

2 Basil Johnston, "The Bear-Walker" in Basil Johnston, The Bear-Walker and Other Stories (Toronto: Royal Ontario Museum, 1995) 7.

3 Truth and Reconciliation Commission of Canada, "Honouring the Truth, Reconciling for the Future: Summary of the Final Report for the Truth and Reconciliation Commission of Canada" (June 2015) at 215.

4 For example, in the seminal 1990 Aboriginal rights case $R v$ Sparrow, the Supreme Court of Canada found that "a morally and politically defensible conception of aboriginal rights will incorporate both [aboriginal and non-aboriginal] legal perspectives" and that it is therefore "crucial to be sensitive to the aboriginal perspective itself on the meaning of the rights at stake." More recently, the landmark 2014 Aboriginal title decision Tsilhqot'in Nation v British Columbia reiterated that determinations of Aboriginal title "must be approached from the common law perspective and the Aboriginal perspective" and that "[t]he Aboriginal perspective focuses on laws, practices, customs and traditions of the group." ${ }^{4}$ v Sparrow, [1990] 1 SCR 1075 at 1112; Tsilhqot'in Nation v British Columbia, 2014 SCC 44 at paras 34, 35 (emphasis added). 
He suggested that "[a] more widely applicable concept of honour imposes on all members of the legal profession the duty to learn: at the very least, to holding ourselves ready to learn ... If the rights of all Canadians, including Aboriginal Canadians are to be guarded and articulated by the courts, the courts must necessarily be capable of guarding the nature of those interests." ${ }^{5}$ If we accept the TRC's call to action, and Finch CJ's proposition that there is a "duty to learn" about Indigenous legal orders, the question shifts to "how"? How can we provide members of the legal profession with effective and enriching opportunities to learn about Indigenous legal orders?

There are certainly no simple answers to this question. As the Anishinaabe legal scholar John Borrows points out, there are numerous diverse Indigenous legal orders found across Canada, and each one is likely as difficult to learn, if not more so, as the Canadian legal system. ${ }^{6}$ This reality does not mean that the challenge is insurmountable. The most practical place to start cultivating respect and appreciation for the complexity and sophistication of Indigenous legal orders within the legal profession is likely inside our law schools. As the Finch CJ suggests, it may be "unrealistic to expect the current generations of judges and counsel to achieve the shift in perspective necessary to incorporate Indigenous legal systems into the existing order. However, those at the beginnings of their legal careers and educations have the advantages of time and resources at their disposal. They are best positioned to gain an appreciation of context and foreclose the calcification of perspective."

This article investigates educational strategies that law schools could implement in order to honour the recommendations of the TRC and foster strong intercultural interpretation and communication skills among new generations of legal professionals in relation to Indigenous legal viewpoints as well as related challenges. In exploring this question, I draw from three main sources: (1) Indigenous legal scholarship; (2) my own experiences of receiving training in Anishinaabek legal traditions at Neyaashiinigmiing 27, a reserve community located on Georgian Bay in the Bruce Peninsula; and (3) existing conversations on teaching Indigenous legal traditions in Canadian law schools. The goal of this article is to help the reader imagine in concrete terms what the study of Indigenous law in Canadian law schools might look like moving forward.

This article is divided into four sections. In the first section, I draw on Indigenous legal scholarship to explore definitions of Indigenous law; in the second section, I provide a case study of one method of learning Indigenous law based on my personal experiences of being taught Anishinaabe law at Neyaashiinigmiing; in the third section, I discuss some of the rich initiatives, opportunities, and challenges involved in integrating Indigenous legal traditions into the curriculum of Canadian law schools using the University of Victoria Law Faculty as a case study; and in the fourth and final section of the article, I highlight a few of the concerns being raised as these initiatives develop and the related need for the legal profession to proceed with caution, humility, and respect.

5 Justice Lance SG Finch, “The Duty to Learn: Taking Account of Indigenous Legal Orders in Practice," paper presented at the "Indigenous Legal Orders and the Common Law" British Columbia Continuing Legal Education Conference in Vancouver (November 2012) at 7, online: British Columbia Continuing Legal Education $<$ http://www.cle.bc.ca/onlinestore/productdetails.aspx?cid=648> [Finch, "The Duty to Learn"].

6 See John Borrows, Canada's Indigenous Constitution (Toronto: University of Toronto Press, 2010) at 59-104 [Borrows, Canada's Indigenous Constitution]; John Borrows, "With or Without You: First Nations Law (in Canada)" (1996) 41 McGill LJ 629 [Borrows, "With or Without You"].

7 Finch, "The Duty to Learn," supra note 5 at 20. 


\section{DEFINING INDIGENOUS LAW}

Following the scholarship of Cree/Gitxsan legal scholar Val Napoleon, I use the term "Indigenous legal traditions" throughout this article to broadly encompass various Indigenous legal orders (the structure and organization of laws) and Indigenous laws within those orders. ${ }^{8}$ As Napoleon explains, the term "legal system" may be used to describe a state-centred legal system where law is managed by legal professionals in legal institutions that are separate from other social and political organizations. In contrast, the term "legal order" may be used to describe law that is embedded throughout social, political, economic, and spiritual institutions. The Canadian state may be said to use a legal system, while Cree and Dunnezah people, for example, have traditionally relied upon a legal order. ${ }^{9}$

Due to the diversity of First Nations peoples across Canada, there is no one Indigenous legal order. ${ }^{10}$ According to the Borrows, "[the] underpinnings of Indigenous law are entwined with the social, political, biological, economic and spiritual circumstances of each group. They are based on many sources including sacred teachings, naturalistic observations, positivistic proclamations, deliberative practices and local and natural customs." "While, historically, there has been relatively little legal scholarship exploring the diverse content of Indigenous legal traditions, ${ }^{12}$ the entrance in recent decades of greater numbers of Indigenous people into law degree programs at the undergraduate and graduate levels has resulted in an emerging body of rich scholarship on Indigenous law. ${ }^{13}$

Scholar James Youngblood Henderson has suggested that Indigenous legal traditions are best accessed in the context of language, stories, methods of communication, and styles of performance and

8 Val Napoleon \& Hadley Friedland "Indigenous Legal Traditions: Roots to Renaissance" in Markus Dubber, ed, Oxford Handbook of Criminal Law (London: Oxford University Press, 2014).

9 Val Napoleon, “Thinking about Indigenous Legal Orders," Research Paper for the National Centre for First Nations Governance (June 2007), online: National Centre for First Nations Governance <http://fngovernance.org/ncfng_research/val_napoleon.pdf>.

$10 \quad$ Ibid.

11 Borrows, Canada's Indigenous Constitution, supra note 6 at 23-24.

12 A relevant body of work from the discipline of anthropology and the sub-discipline of legal anthropology does exist; see, for example, Karl Nickerson Lelwellyn \& Edward Adamson Hoebel, The Cheyenne Way: Conflict and Case Law in Primitive Jurisprudence (Norman, OK: University of Oklahoma Press, 1941).

13 In the Canadian context, see, for example, JY Henderson, First Nations Jurisprudence and Aboriginal Rights: Defining the Just Society (Saskatoon, SK: Native Law Centre, 2006); K Bluesky, "Art as My Kabeshinan of Indigenous Peoples" (LLM thesis, University of Victoria, 2006) [unpublished]; Borrows, Canada's Indigenous Constitution, supra note 6; Val Napoleon, "Who Gets to Say What Happened? Reconciliation Issues for the Gitxsan" in Catherine Bell \& David Kahane, eds, Intercultural Dispute Resolution in Aboriginal Contexts (Vancouver: UBC Press, 2004) 176-195; Val Napoleon, "Looking beyond the Law: Questions about Indigenous Peoples' Tangible and Intangible Property" in Catherine Bell \& Robert Paterson, eds, First Nations Cultural Heritage and Law: Reconciliation and Reform, vol 2 (Vancouver: UBC Press, 2008); Wenona Victor, "Indigenous Justice: Clearing Space and Place for Indigenous Epistemologies," Research Paper for the National Centre for First Nations Governance (December 2007), online: National Centre for First Nations Governance <http://fngovernance.org/ncfng_research/wenona_victor.pdf>; Christine Zuni Cruz, "Law of the Land: Recognition and Resurgence in Indigenous Law and Justice Systems" in Benjamin Richardson, Shin Imai \& Kent McNeil, eds, Indigenous Peoples and the Law: Comparative and Critical Perspectives (Oxford: Hart Publishing, 2009). 
discourse because these are mediums that frame understanding and encode values. ${ }^{14}$ These are the mediums used to communicate Indigenous law to the family and to the community, by conceptualizing values and good relationships. In the process of transmitting and negotiating Indigenous law, Elders (particularly those that are fluent in an Indigenous language) and other particularly knowledgeable community members will be the primary authorities for interpreting First Nations jurisprudences. ${ }^{15}$ Henderson also posits that First Nations jurisprudence exists not as a rigid set of rules but, rather, as a set of interlocking and overlapping processes (including storytelling, perceptions, sensations, and a variety of activities) that collectively make up teachings, customs, and agreements. He compares these overlapping processes with the synesthetic tradition of early Greek and Hebrew societies, noting that First Nations jurisprudence and law are communicated through a broad range of media that encompass "the entire sensory spectrum," using sound, touch, sight, taste, and smell to communicate and reinforce legal meanings. ${ }^{16}$

Indigenous legal traditions manifest themselves through social experiences that involve people communicating with one another about how best to conduct relationships and resolve disputes. ${ }^{17}$ The practice of Indigenous law involves an ongoing process of negotiation, discussion, and compromise. Underlying principles and shared understandings provide the framework in which these negotiations occur. As theorist Robert Cover explains, "[a] legal tradition ... includes not only a corpus juris but also a language and a mythos - narratives in which the corpus juris is located by those whose wills act upon it. These myths establish a repertoire of moves - a lexicon of normative action - that may be combined into meaningful patterns culled from meaningful patterns of the past." 18 The language and mythos that underlie particular Indigenous legal orders form the underlying framework in which debates and negotiations occur. This framework provides the basis for the choices and strategies that individuals and groups may choose to draw on when faced with challenge or conflict.

\section{LEARNING ANISHINAABE LAW AT NEYAASHIINIGMIING}

As a non-Indigenous Canadian citizen, I did not learn about Indigenous legal traditions until I was in law school and took a summer research job with the Indigenous Bar Association. Following the completion of my second year as a juris doctor [JD] candidate at Osgoode Hall Law School, I was hired to serve as a student researcher on a national Accessing Justice and Reconciliation Project [AJR Project] on the revitalization of Indigenous law. ${ }^{19}$ The project was supervised by Val Napoleon and jointly funded by the Law Foundation of Ontario, the Truth and Reconciliation Commission, and the Faculty of Law at the University of Victoria. The project partnered with seven Indigenous communities and engaged with six distinct Indigenous legal traditions across Canada to identify responses and resolutions to harms and conflicts within Indigenous societies. I was one of several law and graduate student

14 James Youngblood Henderson, First Nations Jurisprudence and Aboriginal Rights: Defining the Just Society (Saskatoon, SK: Native Law Centre, 2006) at 127.

15 Ibid.

16 Ibid at $165-166$.

17 Borrows, Canada's Indigenous Constitution, supra note 6 at 10.

18 RM Cover, "Nomos and Narrative" (1983) 97 Harv L Rev 4 at 9.

19 For more information, see the Accessing Justice and Reconciliation Project <http://www.indigenousbar.ca/indigenouslaw/>. 
researchers employed on this project to investigate (with the crucial assistance of community members) oral histories and Indigenous legal traditions relating to justice and reconciliation. As a part of this work, I was placed for three months at Neyaashiinigmiing (formerly known as the Cape Croker Indian Reserve) on Georgian Bay in the Bruce Peninsula and was assigned to work with two other individuals for the duration of the summer - law student and Neyaashiinigmiing band member Lindsay Borrows and university instructor, band councillor, and ecologist Tony Chegahno.

My experience of being taught about Anishinaabe legal traditions at Neyaashiinigmiing was unlike any learning experience I have previously had, and it enlarged my understanding of what constituted legal education in profound ways. Two statements made to me by community members early on in my stay encapsulate this enlargement and had a deep resonance for me by the time I left Neyaashiinigmiing. The first of these statements was made by Lindsay's Anishinaabe grandmother, Jean Borrows, who, after listening in one day on one of our storytelling sessions with a small group of community members, smiled with satisfaction and said: "Yes, that's right. Teach them the principles and they will govern themselves." The second statement was made by my friend Neepitapinaysiqua in the context of a discussion about some new environmental bylaws that had been passed by the band council, banning people from throwing refuse into the streams or lake on the reserve. Lindsay and I had gone to visit Neepitapinaysiqua in her home at the Maadooki Senior's Centre to tell her about the new legislation, expecting her to be pleased since we knew she cared deeply for the health of the water and desired greater protection for it. Instead of becoming excited, however, she looked sad and shook her head saying: "Laws are for the lawless." I will return to these two statements and how my understanding of them deepened over time after describing the teaching strategies that were used to help me learn and practise Anishinaabe law during my summer research work.

\section{A. Learning Anishinaabe Law from Stories}

Approaching traditional stories as legal cases and as a source to access Indigenous law was first suggested by leading Anishinaabe scholar John Borrows, who has proposed that Indigenous stories are similar to common law cases for a number of reasons: they relate disputes and their resolutions; they are regarded as authoritative by their listeners; there are natural and social consequences that result from the violations of the instructions contained in them; and, finally, the interpretation of the stories promotes personal and collective adherence to the underlying values and principles. ${ }^{20}$ Due to these similarities, he has argued that Indigenous nations may look on their stories as a body of knowledge that functions in a manner similar to case law precedent. ${ }^{21}$

Building on Borrows' work, legal scholars Val Napoleon and Hadley Friedland have developed a rigorous methodology based on analyzing and synthesizing legal principles from Indigenous stories. ${ }^{22}$ Their methodology brings together a common pedagogical method from many Indigenous legal orders

20 Borrows, "With or Without You," supra note 6 at 647-648.

21 Borrows also points out that there are many ways in which Indigenous stories function differently from common law case law. For example, Indigenous stories have traditionally been passed down orally rather than in written form. This allows speakers to modify certain details in the story to make them more relevant to the listeners while still maintaining the core principles of the stories. Ibid.

22 For a detailed discussion of why and how they developed this methodology, see Napoleon \& Friedland, "The Inside Job," supra note 3 . 
(stories) and the case method of common law legal education (legal analysis). It extends Borrows' approach by applying an adapted case method analysis to ask specific research questions of multiple published stories and oral traditions within specific communities. Napoleon and Friedland emphasize that just as Canadian law cannot be learned from one case, Indigenous law cannot be learned from a single story. ${ }^{23}$

As a legal researcher already trained to case brief common law rulings, I did not find the transition to creating case briefs for Anishinaabek traditional stories an especially difficult leap to make. According to Napoleon, while there are many starting points of access for learning Indigenous law, learning to case brief traditional stories may be the most natural and comfortable starting point for law students that have already begun training in the common law. ${ }^{24}$ My experience was that, although the task of case briefing Indigenous stories is hard work (as is the task of case briefing common law rulings), the familiarity of the exercise helped to provide an initial bridge between my previous common law training and the first weeks of beginning to learn Anishinaabe law. That said, I do not wish to overemphasize the commonalities between judge-authored decisions and Indigenous stories. Perhaps the most important of these differences is the way that Indigenous stories are intended to engage listeners holistically - that is to say, spiritually and emotionally as well as intellectually.

To provide an example that will help the reader to understand the process that the other law student and I engaged in, the following is an excerpt from a case brief I prepared of an Anishinaabe story called "Toad Woman." In the common law tradition, it is possible for a single case to stand for several precedents in different areas of law. Similarly, a single Anishinaabe story may also be drawn on to show a number of precedents in procedural and/or substantive law. Although there are several legal principles that emerge from the story of "Toad Woman," which deals with the kidnapping of a baby, I focus in this sample case brief on a procedural issue concerning evidence:

Sample Case Brief

Story Title: Toad Woman ${ }^{25}$

Issue: In the absence of an admission of guilt, how can a decision maker be confident that an alleged harm has actually occurred?

Facts: A young mother goes out to gather food and leaves her infant son alone at home tucked into a wampum cradle. Before leaving, she gives her dog instructions to guard the infant while she is out. While the mother is gone, Toad Woman enters the house and picks up the child in his cradle. The dog attempts to prevent the kidnapping by holding onto the cradle with his teeth. He is unsuccessful in stopping Toad Woman from taking

23 For a comprehensive discussion of their methodology and each of these four elements, see Hadley Friedland \& Val Napoleon, "Gathering the Threads: Developing a Methodology for Researching and Rebuilding Indigenous Legal Traditions" (2015) 1 Lakehead LJ 16, online: <http://lij.lakeheadu.ca>.

24 Val Napoleon, presentation given at Indigenous Bar Association Conference, Winnipeg, Manitoba, 16 October 2012.

25 "Toad Woman" in L Mentor, Schoolcraft's Indian Legends (East Lansing, MI: Michigan State University Press, 1991) at 83. 
the child; however, in the struggle the dog tears off a small piece of the cradle and is left with it in his mouth.

When the mother returns home, she is devastated to find that her baby has been taken. Finding the ripped piece of her son's wampum cradle, she leaves to find him. The mother searches for many years but is unable to locate her son until he has already grown into a young man. He has been raised by Toad Woman who treated him as her own son and led him to believe that she was his actual mother.

The mother tells her son the truth of what happened when he was a baby and presents him with the ripped piece from his wampum cradle. Unsure whether to believe the accusation, the son returns to Toad Woman's home and confronts her. Toad woman continues to pretend to be his real mother, until he forces her to produce the wampum cradle at which point he matches up the torn piece and finds that it corresponds perfectly to a missing part of the cradle.

Decision: Once the son sees the physical evidence, he is convinced of Toad Woman's guilt, despite her continued refusal to admit to having kidnapped him.

Reasoning: The reasoning for the son's decision is implied rather than explicitly stated; however, it appears that while the accusation of his birth mother against Toad Woman alone was not enough to convince him that he had been kidnapped, her testimony in combination with the physical evidence was sufficient to persuade him.

This case brief of the Anishinaabe story of "Toad Woman" is likely a familiar template to anyone trained in the Canadian common law. As mentioned above, it is impossible to know Anishinaabe law on a particular issue based only on one story, just as it is not possible to know Canadian common law on a particular issue based only on one judgment. Instead, it is through considering a number of stories in combination, possibly alongside other sources of law, that a strong understanding of an Anishinaabe legal perspective on a given issue may be reached. To continue with the issue of evidence introduced above through the story of "Toad Woman," in order to learn about this aspect of Anishinaabe law over the course of the summer I read a number of stories that addressed the questions of how to establish if a harm had occurred and also interviewed several community members in order to elicit their understandings of the topic. At the end of the summer of research, I created an integrated synthesis based on the principles contained in all of the stories that I had read, in addition to the input and commentary from community members. In this final integrated synthesis, the use of physical evidence such as the torn piece from the wampum cradle to corroborate oral testimony was one component of a broader Anishinaabe approach to the use of evidence in establishing whether a harm has been committed.

The experience of immersing ourselves in Anishinaabek stories was an attempt to beginto acquaint ourselves (in a very short space of time) with the narrative universe inhabited by the Elders and other community members we were to work with over the summer. To return to the passage from Cover's Nomos and Narrative cited in the first section of this article, "[a] legal tradition ... includes not only a corpus juris but also a language and mythos - narratives in which the corpus juris is located by those 
whose wills act upon it. These myths establish the paradigms for behaviour." 26 Learning the stories in preparation for our visit to the community was an attempt to begin to understand the intellectual, social, and spiritual universe out of which the laws we were studying were derived. Although the process was both preliminary and incomplete due to the short time frame and limitations (language being a key limitation since I do not speak Anishinaabemowin and had to rely on English translations), the work of reading the stories was still very useful in beginning to understand the values, ideas, relationships, and environment from which Anishinaabe law has evolved.

\section{B. Learning Anishinaabe Law from Community Members}

As well as learning Anishinaabe law from stories, we were also taught by thirteen community members from Neyaashiinigmiing. These community members were individuals who had (mostly) grown up on the reserve, were knowledgeable about Anishinaabe stories and values, and, in some cases, were fluent speakers of Anishaabemowin. One of these community members was the late celebrated storyteller and linguist Basil Johnston. In an interview that we conducted with him, Johnston estimated that he knew approximately 600 Anishinaabe stories by heart and could tell them in both English and Anishinaabemowin. ${ }^{27}$ Speaking with community people who had a deep knowledge of the stories as well as years of experience of seeing how disputes were resolved within an Anishinaabe community context added new layers of meaning to the understandings of Anishinaabe legal principles that we had begun to arrive at through reading and case briefing the stories on our own prior to arriving in the community.

In his interviews with us, Johnston clarified some of the philosophical assumptions that underpinned the Anishinaabe stories we were reading and also helped us to understand how this world view might manifest itself in everyday actions including situations involving disputes. For example, he explained that the Anishinaabe world view is characterized by a quality of intellectual humility and directed us to consider the Anishinaabe word for truth: w'daeb-awae. He told us that Anishinaabe society has traditionally been distrustful of the concept of absolute certainty and that the word w'daeb-awae literally translates to saying that "[a] speaker casts his words and his voice only as far as his vocabulary and his perception will enable him." 28 Johnston explained to us that when testimony is being given in a dispute context both speakers and listeners are mindful of, and guided by, the Anishinaabe proposition that no speaker has access to the whole truth. He also pointed out that in the context of Western trials Anishinaabe people may make poor witnesses because they are likely to agree with opposing counsel that events could have unfolded in a different way than what they had testified. ${ }^{29}$

In addition to sharing substantive knowledge about Anishinaabe law, language, and world view, the community members that we worked with also told us about their experience of learning Anishinaabe stories and law. One elderly woman, Neepitapinaysiqua, told us that learning stories was "the serious work of the winter." 30 As a child, she remembered being told stories along with her brothers and sisters by her parents, grandparents, and other adults all through the winter months. She stressed to us that

\footnotetext{
Cover, supra note 18 at 9.

Personal interview with Basil Johnston in his home at Neyaashiinigmiing, 27 June 2012.

Basil Johnston, “One Generation from Extinction” (1990) 124-125 Canadian Literature 13.

Interview with Basil Johnston, supra note 27.

Interview with Neepitapinaysiqua at her home in the Maadooki Senior's Centre at Neyaashiinigmiing, 24 June 2012.
} 
learning these stories was by no means a passive process and that she and her siblings were expected to actively grapple with the stories by asking questions, comparing them to other stories, and using them to apply to situations they saw around them. She told us that in her household the stories were regarded very seriously and were so important to her that when she left Neyaashiinigming at the age of sixteen to work and discovered for the first time that people outside of her community did not believe in them she was devastated. The pain of that memory was so powerful that even though it occurred many years ago, she wept recalling it for us in our interview.

Neepitapinaysiqua, Johnston, and the other community members that we spoke with at Neyaashiinigmiing taught us Anishinaabe law in the same manner that they themselves had been taught it as children: they told us stories, provided explanations for us on points we were confused about, asked us questions, helped us to make analogies and spot differences, teased us and joked with us, and gently argued over the meanings of the stories we were discussing. The interactions we had with community members reinforced the fact that Indigenous law (like other legal systems) is a social system and not merely a set of rules. They encouraged us to interact with Anishinaabe law as a living, breathing entity one that we could argue with, shape, and contribute to as well as learn from.

\section{Learning Anishinaabe Law from the Land}

In addition to learning from stories and community members, we also learned Anishinaabe law from the land at Neyaashiinigmiing. The reserve is located on the edge of Georgian Bay on the Bruce Peninsula. There are enormous limestone bluffs overlooking the water and fossils scattered on the shores of the lake dating back thousands of years to a time when the area was a tropical reef. ${ }^{31}$ The land is forested and home to numerous wildlife, including bears, rabbits, deer, dogs, porcupines, owls, and other birds as well as many species of plants, flowers, and trees. The land and all of its non-human inhabitants (including the rocks and fossils) are viewed by many to be a teacher of Anishinaabe law. In fact, the Anishinaabemowin word for "teacher" is akinoomaagewin - the word "ake" means "the earth," while "noomaagewin" is the verb "to teach"; so the Anishinaabemowin word for teacher literally translates to "earth as teacher." 32

During our time in Neyaashiinigmiing, we were assisted on our research on a full-time basis by ecologist Tony Chegahno. He grew up on the reserve and spent his childhood outdoors as much as possible, by the lake and in the forest, learning about the land through loving observation and from Elders who were able to take the time to teach him. He is currently employed by the Ontario Ministry of the Environment to monitor species at risk in the Bruce Peninsula area. He has a deep knowledge of the ecology of the region and is skilled at knowing how to locate rare plants, recognize a broad range of animal tracks, and identify the calls of owls and birds. While on the reserve, we had the benefit of being taken out on the land by him most days to watch birds and wildlife, to learn to identify plants and their uses, to tell stories, and generally to deepen our understanding of the earth as a teacher.

To help us do this, Tony encouraged us to observe the land closely and to draw out values and principles from what we saw. For example, one day he led us into a difficult-to-access part of the forest in order to show us two trees, both of the same species. One of the trees was healthy and robust looking

31 For more geological information on the area, see Bruce Peninsula National Park, online: <http://allontario.ca/2012/12/bruce-peninsula-national-park>.

32 Basil Johnston, Anishnaube Thesaurus (East Lansing, MI: Michigan State University Press, 2007 ) at 1. 
with a thick trunk and shiny bark, while the other was much frailer and looked punier. He asked us to consider which of the two trees was the stronger, and when we pointed to the healthier looking tree, Tony asked us to look down at the soil that each was growing out of. When we did so, we saw that while the healthier looking tree was firmly rooted in rich, moist soil, the other had somehow managed to spread its roots down into a large slab of bare rock. Tony suggested to us that we might want to remember this tree and its struggle to grow out of such an inhospitable foundation anytime that we were tempted to judge another person as being weak.

Another way in which we learned Anishinaabe law from the land was from the way that the plants, animals, birds, trees, rock formations, and weather patterns reinforced and reminded us of the stories we were learning. The sight or sound of particular aspects of the natural world sometimes moved others to tell particular stories. For example, Neepitapinaysiqua told us that when she was a child her mother would tell her the story "Lone Lightening" whenever there was a thunderstorm. The story is about a little boy who is treated abusively by his family, beaten regularly, overworked, and undernourished. Eventually, the little boy reaches the limits of his endurance and runs out of the house in anguish, calling out to the sky for help. The sky takes pity on him and lifts him up above the clouds where he will be safe. The sky also arms the little boy with lightning bolts that he can use in the future to throw at anybody who might try to hurt him. Neepitapinaysiqua told us that throughout her life, wherever she has happened to be living, the sight of lightning has brought to her mind the little abused boy in the story and reinforced for her the importance of treating children with dignity and respect.

Because so many of the Anishinaabe stories that I had read prior to arriving at Neyaashiinigmiing featured animals, plants, and trees that I saw on a daily basis while living at Neyaashiinigmiing, I was frequently reminded of the stories I was learning. The sight of a porcupine scuttling across the road brought to mind the story of "How the Porcupine Got Its Quills" and the related themes of resourcefulness and vulnerability; ${ }^{33}$ while spotting a stray dog digging would remind me of the story "What the Dog Did" and the consequences of disloyalty and betrayal. ${ }^{34}$ Because of being outside on the land every day, the stories were reinforced by my senses so that I absorbed them more holistically than I would have had I only engaged with them through reading or listening indoors. In this way, I experienced a synesthetic way of learning law.

Borrows observes that one way to understand the territorial jurisdiction of Anishinaabe law is to consider it as extending as far as the boreal ecosystem described in Anishinaabe stories. Of course, this does not preclude other Indigenous legal orders from also being in force where lands and waters are used by two or more nations. ${ }^{35}$ However, in practical terms, an individual trained in Anishinaabe law will be reminded of Anishinaabe legal principles while they are within the ecosystem because Anishinaabe law may be considered to be both derived from the land (through the principle of akinoomaagewin) as well as written on the land through signposts that are visible across the territory. Although the time I spent at Neyaashiinigmiing was relatively brief (three months plus several follow-up visits), I have subsequently found that the learning I did there has stayed with me. Whenever I travel through Anishinaabe territory and see the birch trees, owls, red willows, and other familiar sights on the

33 In this story, porcupine sticks thorns on his skin and asks Nanabozho to make them permanent in order to be able to protect himself from his predators. GE Laidlaw, "Ojibwe Myths and Tales" (1922) 1:1 Wisconsin Archeologist 28.

34 In this story, dog betrays the other animals and, as a consequence, is banished and condemned to live with humans.

35 Personal conversation with John Borrows, in Victoria, British Columbia, 27 July 2013. 
land, I am reminded of the stories and legal principles to which they attach as well as the intimate relational context in which I learned them. I now appreciate what my friend Neepitapinaysiqua meant when she exclaimed to us in disappointment that "laws are for the lawless" after hearing about the new band bylaws in regard to water. A child who has been raised learning Anishinaabe law regarding the care of the water through stories and teachings in a familial context that is continually reinforced through sensory and relational reminders may have a depth of commitment to the legal principles regarding the proper care of water that is much more profound than a band bylaw that is externally enforced through the imposition of fines. As Jean Borrows stated, "[i]f you teach them the principles, they will govern themselves."

\section{TEACHING INDIGENOUS LAW IN LAW SCHOOL: UNIVERSITY OF VICTORIA FACULTY OF LAW AS A CASE STUDY}

The traditional relational and place-based method of transmitting knowledge of Indigenous legal orders presents some unique opportunities and challenges for Canadian law schools seeking to incorporate training on Indigenous legal orders into their undergraduate law degree curricula. While the learning experience I enjoyed at Nayaashiinigmiing was profound, the logistics for law schools of placing large numbers of students in communities are daunting for many reasons: the financial costs, the difficulties of finding willing host communities with the capacity to house and teach students, and commitments in student lives that may make it difficult or impossible for them to relocate to other locations for a portion of their training. However, in spite of these challenges, several law schools are starting to find ways to incorporate place-based learning of Indigenous legal traditions into their curricula.

Although still in the planning stages, the most ambitious program incorporating community-based learning of Indigenous law is the University of Victoria Faculty of Law's proposed Juris Indigenarum Doctor [JID] program. ${ }^{36}$ This program envisions traditional law school classroom learning combined with substantial amounts of time - two full semesters or one quarter of the total program length of eight semesters - spent learning within Indigenous communities. Upon completion of this four-year dual degree program, students would be eligible to receive both a common law degree as well as an Indigenous law degree focusing on particular Indigenous legal orders such as Cree, Anishinaabe, Gitxsan, or Coast Salish. The program will work between the common law and Indigenous law traditions, comparing them, and using one to illuminate the other, exploring points of possible connection and relationship. If adopted, this program would make legal history as there is no similar degree program anywhere in the world. ${ }^{37}$

One of the opportunities that the proposed JID program at the University of Victoria Faculty of Law affords is the chance to build strong relationships with host communities and give students an immersive

36 For more information about the JID program, see The JID Background (26 January 2016), a two-page synopsis of its aim and structure, and The JID Scope and Components (26 January 2016), an eleven-page document that provides more detail on the program's various components. Both documents are made available online by University of Victoria Faculty of Law Dean Jeremy Webber.

37 This description is taken from the proposal approved in principle by the Faculty Council at the University of Victoria's Faculty of Law. Personal communication with John Borrows on 18 June 2014. 
experience in one or more Indigenous legal traditions, such as the type of learning experience I benefited from in learning Anishinaabe law at Neyaashiinigmiing. During their time in placement communities, students might work with Elders who are traditional knowledge keepers of the law, assist lawyers in the community serving Indigenous clients, work at a tribal court, help draft zone bylaws, or help with another project of value to the community. This immersive component of the program will allow students to explore the content and processes of Indigenous traditions, teaching them collaboratively with the communities themselves. Following this intensive engagement with particular Indigenous legal traditions, classroom work would encourage broader reflection on the methods of various traditions and show students how practitioners might engage in structuring relations and modes of reasoning across traditions.

In their piece on trans-systemic teaching in the law school, Roderick Macdonald and Jason MacLean reflect on the role of bijuridical legal education in the Faculty of Law at McGill University where students are educated in both the common and civil law traditions. They state that the bijuridical nature of the McGill program has helped to foster within the McGill law community an "open-ended conversation about law through time." 38 They elaborate by proposing that in "attending to the formal plurality of law projected through time and place, the McGill Programme invites attention to the key questions, processes, and commitments through which a legal education serves to constitute legal knowledge and law." 39 This attentiveness to legal plurality could be pushed further, they suggest, to an openness that extends beyond the two traditions being studied and that, "to the extent transsystemic teaching implies that legal orders under consideration can include those of everyday law, the programme ought to aim at broadening the range of people who are enabled to learn how to seize, wield, and critique law's institutions, normative structures, processes and rhetorical discourses."40

The planned dual common law/Indigenous law degree program at the University of Victoria's Faculty of Law creates an opportunity that is similar to the vision of trans-sytemic legal education articulated by Macdonald and McLean. In being able to learn about the everyday practice of Indigenous legal orders in communities, as I was able to do as a law student at Neyaashiinigmiing, the proposed program may broaden participants' recognition and understanding about what constitutes law and put it into fruitful conversation with other systems of law. Simultaneously, it is possible that sending law students to Indigenous communities to learn from informed local people may empower community members to claim more space for their own legal orders and engage with state legal systems from a position of greater confidence and knowledge.

While the Faculty of Law at the University of Victoria is currently the only law school proposing to implement a program granting a degree in Indigenous law, a number of other law schools have undertaken smaller-scale initiatives to introduce their students to Indigenous legal traditions. For example, students in the Faculty of Law at Lakehead University take a semester-long course called Indigenous legal traditions, which examines the legal orders of various nations from an Indigenous perspective, focusing on Indigenous peoples' own laws, world views, and understanding of their treaties

38 Roderick Macdonald \& Jason MacLean, "No Toilets in Park" (2005) 50 McGill LJ 721 at 730.

39 Ibid.

$40 \quad$ Ibid at 739. 
with the Crown. ${ }^{41}$ A second example is Osgoode Hall Law School, which for the first time in September 2014 partnered with the community at Neyaashiinigmiing to host a four-day "Aboriginal Awareness Camp" about Anishinaabe legal traditions. Approximately forty Indigenous and non-Indigenous students and faculty travelled to Neyaashiinigmiing and participated in four days of workshops and activities led by community members. Similarly, the Faculties of Law at the University of British Columbia and the University of Victoria also host annual Aboriginal Awareness Camps with local First Nations partners, which students and faculty may attend. The Faculty of Law at the University of Windsor recently participated in an Anishinaabe Law Camp at Walpole Island First Nation, which was hosted for the benefit of its faculty members. ${ }^{42}$ On a smaller scale than the proposed JID program, these initiatives aim to broaden law students' understanding of what constitutes law and expose them to Indigenous legal orders, while simultaneously building valuable relationships between law faculties and host communities. $^{43}$

\section{CONCERNS AROUND TEACHING INDIGENOUS LAW IN CANADIAN LAW SCHOOLS}

As Canadian law schools begin to seek ways to incorporate some exposure to Indigenous legal traditions into their curricula, certain cautions are simultaneously being raised. Although the scope of this article does not permit me to engage with these concerns in depth here, they merit reflection and attention moving forward, and I feel it would be remiss not to at least highlight a few of them. Accordingly, I will briefly summarize a few issues that are being raised here in the hopes that conversations around these concerns will grow as the conversation around the teaching of Indigenous legal traditions in Canadian law schools expands and deepens.

One important concern that has been raised in relation to teaching Indigenous law in law schools is the damage that has been done to the health and strength of these traditions as a result of the violence of colonialism and assimilationist policies and the vulnerability that Indigenous legal traditions may be experiencing in some, if not most, communities today as a result of that violence. Leading scholars Val Napoleon and Gordon Christie both warn that it is crucial not to underestimate the extent to which Indigenous law has been undermined by recent colonial history. Napoleon cautions that we "cannot assume that there are fully functioning Indigenous laws around us that will spring to life by mere recognition. Instead, what is required is rebuilding." 44 This concern has important implications for law schools seeking to provide opportunities for students to learn Indigenous legal orders and also raises further questions around what role, if any, Canadian law schools, and the Canadian legal profession more broadly, might seek to play in supporting the revitalization of Indigenous legal traditions. Given

41 “Lakehead University Faculty of Law’s Response to TRC Report,” online: <https://www.lakeheadu.ca/academics/departments/law/aboriginal-law/response-to-trc>.

42 Hannah Askew, "Learning from the Land: Annishinaabe Law Camp at Walpole Island First Nation" (May 2016), online: <http://wcel.org/resources/environmental-law-alert/learning-land-anishinaabe-law-camp-walpole-island-first-nation>.

43 Personal communication with Andree Boisselle, who initiated and organized the Aboriginal Awareness Camp at Nayaashiinigmiing, 27 October 2014.

44 Cited on the "Revitalizing Indigenous Law and Changing the Lawscape of Canada" brochure, online: Accessing Justice and Reconciliation Project <http://www.indigenousbar.ca/indigenouslaw/project-documents/>. 
the too-often destructive history of Canadian law in relation to Indigenous law, ${ }^{45}$ is there any role that Indigenous communities and individuals would wish and trust the Canadian legal community to play in the revitalization process? And, as the revitalization process occurs, to what extent is it possible and advisable for Canadian law schools to engage with teaching Indigenous legal orders as Indigenous communities simultaneously revitalize and strengthen their laws?

Inuit law professor Gordon Christie has suggested that there is a risk that introducing Indigenous legal orders into the curricula of Canadian law schools may distort or harm the revitalization process. One point of tension to which he draws our attention is that while Western legal traditions prioritize the intellectual mastery of the law, Indigenous legal traditions typically balance intellectual aspects of legal practice with physical, spiritual, and emotional aspects. This holistic approach to legal training within Indigenous communities is designed to help individuals integrate legal knowledge into their core selves and ways of seeing the world. As Christie explains, Indigenous legal traditions are ideally "supposed to be at the heart, they become part of you and you don't do bad things." 46 This goal is aspirational since, of course, individuals sometimes fail to live up to shared values in Indigenous societies, as in all other human communities. But Christie worries that removing aspects of Indigenous law such as stories from the community context and teaching them within a Western law school setting may result in an overintellectualization of Indigenous legal resources. If, at any point, the communities look to the law schools for assistance as part of their revitalization efforts, or hire graduates to help them resolve issues in their communities based on their own laws, legal professionals trained in the Canadian system might "lead them down a path which is too intellectualized, makes the stories nothing but values and principles and approaches to problems, an analogue to a Western way of doing things." 47

Relatedly, Christie is worried that Canadian law students who are trained in the common law system may filter the Indigenous legal traditions they are studying through the structure of the common law and the categories and issues it emphasizes, potentially distorting their interpretations of Indigenous law. An example he provides for illustrating this potential problem involved a Canadian law student he assisted who was working in an Inuit community and preparing a legal synthesis on the issue of harms. ${ }^{48}$ In this case, the student analyzed a story about an Inuit hunter who was having meat regularly stolen from his cache. After trying several strategies to stop the thief, all of which failed, the hunter came to realize that it was the spirits of the northern lights who were taking his meat. An Inuit medicine man advised him to leave a portion of meat outside the cache as an offering to these spirits, which he did, and the thefts from the cache subsequently stopped. The law student engaged with the story to learn about Inuit responses to theft but struggled with the deeper lesson of the story regarding relations between spirits and human beings in which she had little training. Christie is concerned that members of the communities that produced particular Indigenous legal traditions may end up finding them less relevant or even

45 For some discussion of the history of troubled relations between Indigenous people and the Canadian legal system, see C Backhouse, "Gender and Race in the Construction of 'Legal Professionalism': Historical Perspectives" (2003), online: Law Society of Upper Canada <http://www.lsuc.on.ca/media/constance_backhouse_gender_and_race.pdf >. 
recognizable based on the way that they may be interpreted or promoted by graduates of Canadian law schools. $^{49}$

The concerns raised by Napoleon, Christie, and others regarding the potential pitfalls that attach to introducing the teaching of Indigenous legal orders in Canadian law schools do not have easy answers. They call our attention to unequal power dynamics and the ongoing impacts of colonialism. It is important that we listen carefully to these concerns as they are raised and that the Canadian legal community move forward respectfully and with caution as we seek to better understand Indigenous legal traditions and the efforts that are currently underway with communities to reinvigorate them. The underlying goal of any efforts to better equip Canadian legal professionals to understand Indigenous legal perspectives should be to decolonize and build healthy, mutually enhancing relationships between Indigenous nations and the Canadian legal system.

\section{CONCLUSION}

This article is prefaced with an epigraph from the former chief justice of the British Columbia Court of Appeal, the Honourable Lance Finch, who argues that Canadian legal professionals have a "duty to learn" about, and from, Indigenous legal traditions. ${ }^{50} \mathrm{He}$ argues that for those of us who are not Indigenous, a crucial component of this learning process is that we must reframe the challenge of "making room" for Indigenous legal orders within the existing Canadian legal system to the challenge of "find[ing] space for ourselves, as strangers and newcomers, within the Indigenous legal orders themselves." ${ }^{51}$ I was fortunate as a law student to have the experience of finding space for myself, and of being welcomed as a stranger and a newcomer, in the Anishinaabe community of Neyaashiinigmiing. It was the most transformative part of my legal education and has had a lasting impact on my understanding of law and the kind of lawyer I strive to be in my everyday practice. Current initiatives within some Canadian law schools, such as the Faculty of Law at the University of Victoria, to provide openings for students to learn from Indigenous legal orders in communities promise at least the possibility of similarly transformative learning opportunities for other emerging legal professionals. Recommendation 28 of the TRC's report will hopefully spur further efforts from law schools to create more and deeper opportunities in this regard.

In addition to the possibility and excitement of new initiatives around teaching Indigenous law in Canadian law schools, there remain unanswered questions and concerns moving forward. Much damage has been done in the recent past through the violence of colonialism, and there is an ongoing legacy of distrust between many Indigenous communities and the Canadian legal system. There is an enormous amount of work to be done to repair the relationship, and law schools need to proceed cautiously, respectfully, and with humility as they seek to incorporate teachings on Indigenous legal traditions into their curricula to ensure that Indigenous/non-Indigenous relations are strengthened and not harmed by these initiatives.

We are at an important moment in Canadian legal education, one that holds the potential to enable us as a profession to serve our clients and society in more just and meaningful ways. A lot of effort and

\footnotetext{
49 Ibid.

50 Finch, "The Duty to Learn," supra note 5.

51 Ibid.
} 
good faith will be required, however, in order for us to realize this potential. The hard work that is necessary cannot be understated. As Doug White, lawyer and former chief of the Snuneymuxw First Nations states, "Indigenous law is the great project of Canada and it is the essential work of our time. It is not for the faint of heart, it is hard work. We need to create meaningful opportunities for Indigenous and non-Indigenous people to critically engage in this work because all of our futures depend upon it."52

52 Doug White, "Revitalizing Indigenous Law and Changing the Lawscape of Canada" brochure, online: Accessing Justice and Reconciliation Project <http://www.indigenousbar.ca/indigenouslaw/project-documents/>. 